\title{
Rethinking open government as innovation for inclusive development: Open access, data and ICT in South Africa
}

Paul Plantinga ${ }^{1 *}$, Rachel Adams ${ }^{12}$

${ }^{1}$ Human Sciences Research Council, Pretoria, South Africa

${ }^{2}$ Information Law and Policy Centre, University of London

*Corresponding author email: pplantinga@hsrc.ac.za

The final version of this article is available here:

Plantinga, P. \& Adams, R. (2020). Rethinking open government as innovation for inclusive development: Open access, data and ICT in South Africa. African Journal of Science, Technology, Innovation and Development. https://doi.org/10.1080/20421338.2020.1746046

\begin{abstract}
Open government has come to be closely associated with innovation for inclusive development (IID). These two areas of practice and research have converged around similar mechanisms aimed at achieving inclusive development outcomes including; open interaction between government, technologists and end-users in the design of policies and services; open, market-oriented approaches to delivering public services and meeting the needs of citizens; and a central role for information and communication technologies (ICTs) in policy development and innovation activities. We argue, however, that an uncritical adoption of open, ICT-oriented practices risks shifting responsibility and trust for governance and development outcomes to largely unaccountable global and national network enterprises. Taking South Africa as our primary focus, including its new White Paper on Science, Technology and Innovation (STI), we note a renewed interest in adopting open government practices in relation to IID. More significant, we suggest, is the emergence of 'grassroots', hybrid civic-technology innovation networks at the fringes of formal open government initiatives. This article considers new questions that arise around how these grassroots movements sustain meaningful interaction with mainstream STI processes, how public officials may engage with such movements in order to meet national development outcomes, and the role of ICT in these spaces.
\end{abstract}

Keywords: ICT, innovation, inclusive development, open government, open data, South Africa

\section{Introduction}

Open government has been broadly touted as a good thing, facilitating greater accountability and increasing citizen participation in government processes and decisions. It is now also closely 
associated with the use of ICTs or 'e-governance' and the demand for a more innovative and collaborative public sector that can dynamically address complex development challenges. Open government rests on an ideological assumption that creating supposedly equal access to government processes and information via digital platforms will promote both inclusive government, that responds to the needs of all segments of the population; and, more recently, inclusive development, as private, non-profit and community-based innovators are able to leverage closer government interaction and data to improve the availability and quality of services for marginalised groups (Smith, Elder, and Emdon 2011).

Yet, in the midst of this broadly unquestioned commitment to the inclusive value of 'openness', studies have shown that open data, for example, does not necessarily result in the inclusive innovation or development outcomes it was imagined to (e.g. Worthy 2015). As early as 2011, Margetts pointed out that many of the efforts to digitalise government and provide open access to government data have been 'developer-led, with highly skilled technology consultants or companies using the data for social or commercial purposes' $(2011,519)$. A question then arises as to whether open data and open government broadly is creating a space for more 'responsible' or 'democratic' innovation processes, enabling external and, particularly, marginalised actors to shape the direction of innovation towards inclusive development outcomes (Smith and Stirling 2017).

In response to this dilemma, this article revisits the notion of open government with a view to assessing its potential value within South Africa's current policy discourse on Innovation for Inclusive Development (IID). We begin by critiquing the assumption that there is something inherent to openness and the use of ICT which produces inclusivity, then consider whether South Africa's approach to openness in STI policy and practice has the potential for realising inclusive development outcomes.

\section{Openness, open government and its tensions}

Open government has become the dominant ideal for government in late capitalism, and is fast becoming a global norm. However, historical accounts of open government reveal the diverse, contested lines of development associated with this concept and its many sub-projects - such as open access and open data (Erkkilä 2010; Birchall 2011; Kosack and Fung 2014) - which have come together in a 'contingent unity' at the present time (Gray 2014, 3). Typical features of this unity include; a broad 'principle of publicity' in governing supported by freedom of expression; institutional openness in the way government entities operate as a way to support consensus-based policymaking; and transparency in how public officials make decisions as a right of citizens to accountable government and democratic control (Erkkilä 2010). Moreover, in recent years, open government has come to be associated with a call for a more innovative and market, or performance-driven, public service. Often this has included forms of government openness that 
support collaboration with (social) entrepreneurs and citizens to solve complex problems (Kosack and Fung 2014).

\section{Open government as a natural, techno-economic evolution}

Today, open government is broadly understood to involve the use of ICTs for opening up decisionmaking in the public sector, by making government more accessible through online access to and automated management of government services (Grönlund, 2010). It serves both as an administrative and organisational vision of efficiency, accessibility and productivity, as well as a political vision of transparency, participation and democracy.

Yet, as Nathaniel Tkacz notes, "'the open" has become a master category of contemporary political thought' $(2012,387)$. The trope of openness rests - in simplest terms - upon the idea that by opening something up, it is made visible for all to see, in its true form. Thus, an open government is one where its citizens can easily see what is taking place inside, including, for example, what decisions are being made. Significantly, this openness is realised through the disclosure of information, meaning that the information disclosed claims a certain propensity towards 'being true' in order to fulfil the idealism of openness (Adams 2018). Indeed, Frederick Schauer explains that 'the free availability of information inclines towards knowledge, it is said, even if it does not guarantee it, and thus the claim is that transparency is somewhere between a highly desirable and a necessary pathway on the road to truth' $(2011,1350)$.

With digitalised open government and the enablement of the electronic and automatic disclosure of information, the data and information released is assumed not only to be 'true' but also to be politically neutral. This claim to neutrality - which is particularly intense where coupled with technology and technology's own deterministic claim to being politically neutral - is part of the conceptual basis from which ideas of openness and transparency become associated with inclusivity. In this context, 'inclusivity' refers broadly to an objective to actively ensure that otherwise marginalised individuals or groups are represented, considered and receive the necessary priority in policy planning and activities. That there is little inherent in the idea of openness or open government which leads to inclusivity is a central element of the argument we set out in this article.

Open government constitutes an inexorable step in the maturing of digital government and, more broadly, the constant progress of a technologised society. The shroud of inevitability in which open government has been presented has enabled its quiet acceptance and deterred critique of its effects. Developments in technology have not only characterised late modernity, but have been presented as inevitabilities, such that the rise of open or e-government has been described as 'the next step in the natural evolution of how government services respond to changes in the broader economy and society' (Howard 2001, 6). However, this narrative which portrays open government 
as a 'natural evolution' presupposes, first, that developments in technology are both distinct from the sphere of government and came before a theory of technologised ways of governing; and second, that technological developments are natural, that is, they are expected and unquestionable in an enlightened and progressive society, and therefore, ostensibly, good for all. Tkacz's critique of openness as a 'master signifier' names just this: a concept which has been so naturalised it is considered part of the way things are, and is rendered beyond critique. But Tkacz's reference is also to the Lacanian notion of the master signifier (Lacan 1991): an idea so powerful that it brings together under its semantic signification other powerfully loaded notions, such as, in this case, democracy, accountability, development, and inclusivity. The concern of openness as a 'master signifier' is that it both escapes critique - insofar as it is presented as inevitable and good for all, and therefore shuts down any potential counter-arguments to its ostensible value, and that its meaning is blurred with other notions that are considered good within society (such as democracy, inclusivity and so on), such that it is, again, rendered unquestionable and, takes on an assumed value simply through its association with these other notions.

It's immutable character means that the political implications of what an open or inclusive society requires, or even demands, from its citizens is rarely articulated in public discourse. However, for Tero Erkkilä, the focus on openness is significant in marking a shift in political responsibility away from government and into the hands of 'citizens, interest groups and market actors' $(2010,368)$. While this may sound reasonable for most contexts, particularly where there are high levels of corruption or ineffective service delivery, others have noted how significant differences in access to government information, especially when mediated by expensive or unavailable ICTs, lead to unequal participation and influence over decision-making (Adams and Adeleke 2016). Therefore, the implication here is both that there is little inherent in openness and associated ICTs that leads to inclusivity, and that the shift in responsibility Erkkilä speaks of is not to the wider public, but rather to well-resourced, technologically-skilled individuals and groups (e.g. those that can develop code or analyse open data). This means that we are placing our trust 'in new actors whose trustworthiness is yet to be proven and who are subject to none of the checks and balances that governmental systems have developed' (Margetts 2011, 520). So, for Tkacz, the 'master signifier' of openness must be challenged by 'look[ing] more closely at the specific projects that operate under its name - at their details, emergent relations, consistencies, modes of organising and stabilising, points of difference, and forms of exclusion and inclusion' $(2012,404)$.

Clare Birchall contributes to a closer analysis by exploring the new class of citizenship demanded by open government, which she defines as the 'datatariat': 'a "class" encouraged to make use of and be used as data; a mass connected through data access, production, accumulation, and exploitation' $(2014,26)$. Birchall identifies two kinds of data-driven citizen-identities. First, the citizen that is subject to 'dataveillance', such as a transport authority collecting data on our daily movements for traffic planning. This first model of citizen is central to concerns around personal data collection and potential loss of privacy, for, as Henman (2010) notes, in an e-governed society, 
citizenship itself is preconditioned on the citizens' ready handing over of their information and data.

The second model of citizen Birchall schematises, and which is of greater interest to us here, is the citizen invited to engage with data 'only when this contributes to the entrepreneurial economy ("come and join our datapalooza!") or responsibilised individualism ("look at our pollution data by area code and make a choice as to where you want to live”)' $(2014,43)$.

Birchall's critique points to the workings of a broader governmental order which seeks to produce (largely individualised, economic) subjects that will continue the order of openness and technology through entrepreneurial data activities. This project is, we argue, fundamentally exclusionary insofar as it is based on a singular idea of a 'successful' or 'valuable' citizen, to the exclusion of those that do not or cannot contribute to the 'datapalooza'.

\section{Can open government contribute to more democratic and inclusive innovation processes?}

The techno-economic character of current open government projects is intertwined with emerging approaches to public sector and social innovation. In these environments public servants are encouraged to use open technologies and adopt practices from the start-up community that are more agile, lean and user-centred in how they develop policy and in how projects are implemented (OGP 2011, UK Government 2016, Jonnalagadda and Maier 2019, OECD 2019). By opening up decision-making and supporting an iterative design process, public entities in a number of countries have been able to develop policies that better address local needs, whilst mitigating some of the concerns with openness outlined in the section above. However, the complexity and tradeoffs involved in public policy environments means that agile and user-centred approaches cannot be applied generally. In many cases the needs of different 'users' are contradictory (e.g. between environmental groups and energy companies) and affected actors, particularly in marginalised areas, are not necessarily equipped to make input on a policy issue or project (Moilanen 2019). More broadly, as we have noted, the strong emphasis on technology and a compliant 'datatariat' means that emerging processes of public sector and social innovation adopt an inherently exclusionary character.

Whether governments' innovation processes can support meaningful inclusion of marginalised groups has been a concern for a number of scholars and practitioners involved with responsible and other 'inclusive' forms of innovation. In particular, research on 'grassroots' innovation has sought to engage with the tension between techno-economic (typical of Birchall's datatariat) and more 'democratic' forms of innovation, and is therefore relevant to the relationship between open government and IID. 
As with inclusive innovation, grassroots innovation is a fluid and contested term, but is generally associated with 'alternative forms of knowledge creation and processes for innovation [which] harness local ingenuity directed towards local development' (Fressoli et al. 2014, 277). Work in this field is therefore more explicitly concerned with how innovation is (self-) organised amongst residents of a local area to empower community members and improve their living conditions. However, whilst grassroots initiatives are often regarded as 'neither formally constituted by innovation institutions nor [...] linked into decision-making processes of conventional innovation policy' (Smith and Stirling 2017, 80), these 'movements' inevitably interface to mainstream STI processes in some way (Fressoli 2014). As a result, an important feature of this work is whether and how the interests of grassroots innovators in more marginalised contexts are acknowledged, absorbed or rejected in formal innovation policies and programmes; pointing to possible mechanisms by which grassroots innovators are required to perform (or contest) the role of technoeconomic subjects or citizens in open government initiatives.

One of the more prominent practices for fostering grassroots innovation has been the adoption of open innovation platforms by public sector and non-governmental organisations. Often supported by web-based technologies, open innovation platforms are seen to facilitate knowledge exchange, support collaborative problem solving and level power imbalances between grassroots groups and mainstream actors. In reality, open innovation practitioners tend to underestimate the complexity and time needed to address information asymmetries and associated power imbalances (Cullen et al., 2014), but there is also often an underlying conflict between the values of different stakeholders (Grotenbreg and Altamirano 2017). Smith and Stirling note that for many grassroots innovators, while there may be clear economic benefits of an emerging technology or practice, there is a strong intent to ensure that these benefits do not 'contradict other values such as social inclusion or environmental sustainability' (2017, 76). However, when grassroots initiatives interface to mainstream processes oriented to performance and market-based models of service delivery,

official interest [in grassroots innovation] goes little further than programs to package, scale-up and roll-out ingenious initiatives arising from grassroots activity. They present little more than an attempt to insert grassroots ideas and devices into existing systems and institutions for innovation: for example, turning initiatives into social enterprises or marketable artefacts. There is rarely any attempt to try to understand the broader origins, implications and possibilities of grassroots involvement in new, more democratic forms of innovation $(2017,69)$.

Thus, as with the evolution of open government priorities, it appears that current attempts at supporting inclusive forms of innovation are primarily an extension of state efforts to build more market-oriented approaches to governance and the delivery of public services. In this sense, the endorsement of grassroots innovation appears in effect to contribute to the creation of an individualised techno-economic citizen, valuable to the state only in terms of their efforts - 
whether grassroots or otherwise - to support the commercialisation of local capabilities or resources (including their personal or community data), which ultimately results in disproportionate benefits for intermediaries and external entities (Heeks and Shekhar 2019). Below we consider whether emerging open government practices in South Africa can enable an approach to STI policy implementation that supports meaningful grassroots action in marginalised communities, and thus better support inclusivity.

\section{Open government and innovation for inclusive development in South Africa}

In South African public policy, a discourse and plan of work is consolidating around the notion of IID. In this context, IID is defined in a draft IID Strategy by the Department of Science and Innovation (DSI) (previously the Department of Science and Technology (DST)) as 'innovation that enables all sectors of society, to enjoy equality and equity in access to the knowledge infrastructure, participate in creating and actualizing innovation opportunities and enable individuals to share in the benefits of innovation to advance development goals' (DSI 2016).

Open government figures within this discursive arrangement as both an inclusive innovation in itself, in the use of open technologies as part of government service delivery, and as a mechanism for enabling inclusive innovation. South Africa's new STI White Paper (DSI 2019) readily links openness with inclusivity through a number of open instruments, including:

- pursuing more open forms of STI policymaking involving sector departments and nongovernmental actors;

- opening access to public funded research and data;

- encouraging the use of open government data;

- exploring the role of ICT and the 'fourth industrial revolution' (4IR) in supporting an inclusive knowledge economy;

- opening government procurement to support innovation by small enterprises;

- facilitating co-design between government officials, innovators and end-users; and

- brokering knowledge and resource exchanges between large and small innovation actors.

In the following sections we focus on three closely linked instruments: open access, open data and the 'pivotal' role of ICT as an enabler of open knowledge exchange (DSI 2019, 17). Specifically, we examine how these instruments are linked to inclusivity and IID in current STI-related policy documents and formal open government programmes; but also in more informal grassroots activities and a wider public discourse on open government and innovation.

\section{Open access research and open data}


The South African government and associated agencies are mandating or encouraging open access policies for public funded research (STI White Paper 2019, 52; NRF 2015, 2019). These policies are reflected in the development of open, web-based institutional repositories at many universities, and in shared national research infrastructures. For example, the Data Intensive Research Initiative of South Africa (DIRISA) ${ }^{1}$ aims to enable 'safe' sharing of research data within and outside the research community. There are also more sector-focused platforms such as the BioEnergy Atlas for South Africa $^{2}$ which aggregates scientific research and government administrative data to support policy making and investment decisions in this field. DSI's dual social and economic goals for the platform are to 'have a significant impact on job creation (seasonal and permanent) and improve energy access' for communities not receiving energy services, whilst supporting 'research to improve the competitiveness of local innovations in this sector' (Pandor 2017). The co-existence of social and economic goals is widespread in open government and open innovation programmes which has led to cases of conflicting values, as highlighted earlier, and resistance by participants. For example, researchers may prefer to seek out reputational and social impact by publishing on open access repositories instead of complying with intellectual property legislation and policies which tend to be focused on commercialisation outcomes (Harsh et al. 2017; Ncube et al. 2013).

Similarly, amongst public officials there is a drive to open access to government evaluation research, such as through the Department of Planning, Monitoring and Evaluation (DPME) Evaluations Repository ${ }^{3}$, and in unlocking government data more generally as an enabler for public sector and social innovation. The Open Data South Africa initiative, anchored by the Open Government Partnership (OGP) South Africa programme in the Department of Public Service and Administration (DPSA), is 'encouraging small groups inside and outside of government to explore new applications of (mainly) government data' ${ }^{3}$. In reality it is the more established consulting firms and larger 'groups' that continue to exploit the benefits of public and open data. What public data is available, and how to access and analyse it, is an important competitive advantage for incumbent firms involved in land, property, financial, retail and economic consulting. More recently, South African companies like MTN, a pan-African telecommunications operator, have been sharing private data with public partners to better understand and respond to social challenges, such as communicable disease outbreaks (Shibasaki 2017). Whilst public officials may derive benefits from these relationships, mixing of open and proprietary data can create complexities related to privacy, business models and licensing which can ultimately limit the availability of open data for smaller, local developers and wider user audiences (Hugo and Pauw 2015; de Beer 2017). A further, downstream challenge is ensuring social innovators and policy actors (outside and inside government) are able to understand the often complex or opaque secondary data and models developed by external consultants when crafting economic or social strategies for their province, city or town.

Nonetheless, as awareness of the value of government and other public interest data has increased, so has the number of small technology entrepreneurs experimenting with data-driven, social 
impact applications. Much of the early activity has been in the transport sector, where data has daily relevance to commuters and is less sensitive, so more easily accessed and integrated into applications ${ }^{5}$. The other major growth area has been around governance transparency and accountability where civic technologists have digitised and curated legislation, By-laws, case law, government gazettes, corporate data, parliamentary proceedings, and government spending and budget data ${ }^{6}$. They are also trying to make the data and methods used in social and economic models more open to users, such as in the South African Cities Open Data Almanac ${ }^{7}$. These initiatives have dovetailed with efforts to gather and use citizen-generated data for social impact. Black Sash, an NGO, has collaborated with the DPME to run a Community-Based Monitoring (CBM) programme which conducts local surveys to build 'a strong body of evidence to take back to government and, where necessary, into the public domain, in order to better the delivery of services" ${ }^{\prime}$. Similarly, results from the MobiSAM mobile-phone-based rating and survey application are 'aggregated and used to influence and monitor service delivery' .

In recent years there has been a shift in thinking amongst civic technologists away from external data collection and publishing on national web portals towards stimulating citizen and community agency using local data ${ }^{10}$ that is more meaningful to citizens and communities ${ }^{11}$. Environmental advocacy is at the centre of citizen-science activism, with several community-based and civil society organisations enrolling support from formal scientific-legal organisations ${ }^{12}$ or building their own research and data bases for engaging policy actors ${ }^{13}$. As an example from academia, the Environmental Learning Research Centre (ELRC) at Rhodes University is leading work on a 'transgressive' approach to research 'that seeks to enrich the common good in direct ways that are linked to social activities and practices' ${ }^{\prime 4}$. The ERLC works with organisations like Activate! which supports over 3000 young people across South Africa as 'leaders for public innovation ... a network of change drivers as a new political, social and economic force' ${ }^{15}$. These communitybased or led projects draw on a mix of social and ICT-based innovation and straddle a mix of agendas including synthesising formal and local research or data sources, improving inclusivity and community-based decision-making, informing government planning, and shaming underperforming municipalities or departments.

\section{Open ICT}

For the STI White Paper, ICT is regarded as being 'pivotal' to various other innovation activities - including open access and open data - and underpins 'a dynamic, inclusive and prosperous knowledge economy in which seamless information infrastructure and systems will meet the needs of citizens, business and the public sector' (DSI 2019, 17). As in other countries, the idea of a seamless cyber infrastructure is associated with a broader re-organisation of society towards a 'set of open network structures and activities through which people and information come together' (Smith and Reilly 2013, 3). Whether these open network structures are truly open, inclusive and 
serving the goal of IID is a key question. In South Africa, free and open source software (FOSS) and open access broadband were two of the early rally points for open ICT champions.

Through its agencies, the DSI has promoted the adoption of FOSS in government and open broadband infrastructures, such as the South African National Research Network (SANReN) ${ }^{16}$. As an exemplar of open ICT initiative at a subnational level, the Limpopo Provincial Government (LPG) has sustained their commitment to FOSS and open broadband rollout in the face of significant national inertia. According to the provincial strategy, FOSS is pursued 'for job creation' and 'to assist non-ICT SMMEs to become more sustainable and productive'. Significantly, FOSS 'supports innovation, local solutions and learning' (Limpopo Connexion 2007). As the Limpopo FOSS strategy notes, the national FOSS strategy was never fully implemented and most provinces and government entities in South Africa, as in many other countries, have watered down their openness goals to focus on 'interoperability' and 'integration' (Kelty 2008, 148). The focus has shifted to activating local innovation around pockets of digital openness, such as by equipping emerging developers to use vendors' and government's 'open' APIs and open data.

In the case of broadband infrastructure, the LPG and a number of other city and provincial governments have sought to establish open access fibre or WiFi networks in lower income areas, over which innovative digital services can be delivered to residents. In addition, several government entities have sought to open up the actual network rollout to smaller enterprises, by requiring that portions of the implementation are subcontracted to local, black-owned enterprises. However, as in other sectors; larger network equipment vendors often only enroll small enterprises to support the tender response, usually to meet bid criteria for sub-contracting. Once the contract has been secured, the large vendors then sideline the small enterprises during project implementation (Ngoepe 2018). This 'fronting' is exacerbated by government's inability to enforce openness as demonstrated in an earlier attempt to establish local wireless operators in rural areas. In this case, the regulator was unable or unwilling to regulate fair interconnection between local operators and established national network providers (Gillwald 2005). Similar concern is being expressed about an envisaged industry or state-managed Wireless Open Access Network (WOAN), which is intended to create space for use of high value spectrum by smaller operators. Commenting on the WOAN, Calandro et al. note that, 'openness can reduce investment, perpetuate dominance and requires enforcement once it is found to [be] effective in meeting its objectives' $(2018,15)$.

Whilst FOSS and open broadband formed the core of governments open ICT activities from the late 1990s, in recent years there has been a shift towards providing open innovation and open (online and face-to-face) learning platforms to accelerate the growth of ICT-oriented startups and build a youthful '4IR army'. Coupled to this is an intent to leverage 'government's own appetite for risk and innovation' to inspire and enable 'large scale entrepreneurship' (SANews, 2019). In reality, much of the ICT-related innovation and learning is being stimulated through an eclectic 
mix of local communities (from civic tech ${ }^{17}$ to youth tech ${ }^{18}$, makerspaces ${ }^{19}$, innovation ${ }^{20}$ and crowd-funding ${ }^{21}$ ), many of which have emerged organically at the fringes of formal programmes. These communities are often anchored by relatively skilled individuals with formal work experience or dual roles involving day-to-day corporate, academic or government work but with wider civic interests and relationships to families and friends in marginalised areas. Increasingly, these communities have also sought to engage with mainstream policy issues and critiqued the bias in emerging technologies and associated governance systems, from local \#gkVacWork Tech Debates $^{22}$ to multi-country discussions on AI ethics and policy (Abbott 2019). Further at the fringes are arts, humanities and social sciences scholars who are deliberating and testing ideas and practices that are relevant to 4IR and STI policymaking, such as through the digital arts-oriented Fak'ugesi Festival ${ }^{23}$ and Wits Institute for Social and Economic Research collaboration on digital humanities ${ }^{24}$. Whilst many of these communities and groups originate near government, academic and corporate innovation spaces (such as by being incubated or hosting events in subsidised venues), group leaders are aware that progress cannot be dependent on large public or private entities which can have conflicting interests. Instead, they tend to focus on strengthening internal cooperation and shared benefits, enabling them to engage with government entities and incumbents on more equal terms.

In government and policy circles there seems to be an attempt to engage with or integrate these less-formal networks with mainstream STI policymaking and programmes. Although technologyfocused, the country's Presidential Commission on the 4IR draws on individuals involved in some of these local hubs and communities (South African Government 2019). Meanwhile, National Treasury has interacted closely with $\mathrm{SiMODiSA}^{25}$, a startup-focused association, to shape legislation on intellectual property and technology funding. National Treasury is also collaborating with a civil society coalition as part of the Vulekamali project, by hosting open space meetings in smaller towns across South Africa to gather input from citizens on the priorities and design of a national open budget programme ${ }^{26}$.

\section{Discussion and conclusion}

As the South African government explores more open models of governance, especially in STI and IID policy formulation and programme implementation, we need to ask questions about whether these actions lead to authentic participation by marginalised actors and inclusive development outcomes, what these engagements are motivated by, and what discontents arise from such interactions.

From the above examples it is clear that we need to adopt a broader view on the mechanisms and characteristics of open government and innovation. This reflects de Beer's (2017) observation that much of the current approach to openness and development has been narrowly confined to using ICTs to increase access to knowledge resources (e.g. open access portals) and by focusing on a 
limited number of open innovation processes (e.g. peer-production of open source software) in the formal economy. A result of this narrow focus is that we have privileged the role of ICT in open government initiatives, which marginalised groups have limited access to. We also fail to recognise a more diverse mix of open innovation activities (dual corporate-civic roles, local tacit knowledge exchange) and innovation appropriation strategies (especially in the informal economy), in nonsoftware-related areas.

There is some awareness of this lacuna. In a number of emerging 'open data' projects involving or led by government entities, such as Vulekamali, there are explicit attempts to downplay the role of web-portals and externally generated data by re-directing resources towards citizen interactions, and supporting the development of local intermediaries and even movements instead of simply building 'solutions' (Plantinga et al. 2018). In these local environments there are a multitude of less formal processes by which knowledge is exchanged and resources mobilised; including through social media and other ICTs, but also in more tacit interactions, such as through the temporary labour mobility provided by individuals hosting local communities who have dual corporate or government-civic roles.

Whilst these examples show promise, there is a need to look more deeply at the potential and realised agency of marginalised individuals and groups - as well as government officials, researchers and civic technologists - seeking to shape the direction of innovation towards more inclusive development outcomes. This requires us to think critically about our understanding of openness, open government and IID as articulated by various scholars from both the open government and inclusive innovation research communities. By doing so, we can - as we have begun to do so here - identify the specific mechanisms by which openness and inclusive innovation processes are unintentionally promoting a specific type of individualised, tech-economic citizenship and continually being re-captured by more powerful actors (Smith and Stirling 2017) often by promoting the use of global 'free' and 'open' ICT platforms (Margetts 2011; Singh and Gurumurthy 2014). At the same time, we need to recognise the ways in which marginalised groups may leverage openness to organise and insert, assert or partner with mainstream STI activity such as by leveraging subsidised infrastructure or influencing planning processes - and achieve greater sustainability and inclusivity in innovation (Fressoli et al. 2014; McFarlane 2016).

For grassroots actors, there is spectrum of possible outcomes that they may seek to achieve, from ensuring that externally developed technologies serve the real needs of end users and communities, to enabling participation by disadvantaged individuals in innovation processes, and even changing the structure of R\&D activities at higher levels (Harsh et al. 2017). Engaging with mainstream STI institutions will often involve seeking partnerships to access resources, but it may also require visible or hidden forms of protest, such as local researchers prioritising open access publishing over protection and commercialisation. A common theme in grassroots-led cases, as with South Africa's emerging ICT-related groups, is how innovators mobilise a network of support within 
their community to build political capital and retain independence (or reduce their dependence) when engaging with mainstream institutions (Fressoli et al. 2014). In doing so, such groups make an ideological assertion to re-conceive of openness in a localised and de-centralised manner, that better suits their own objectives.

For government, public officials may seek alternative ways to leverage openness for supporting 'innovation citizenship' in STI policy processes which do not amount to the kind of neoliberalised datatariat imagined by Birchall. As in some of South Africa's recent STI policy processes, this may include increasing gender, disciplinary and geographical diversity in national forums or committees; but also in creating novel spaces for citizens and non-'experts' to contribute to dialogues (Smith and Stirling 2017, 89). Increasingly it also involves engaging with opinions and views from online and social media debates. However, the reality is that most citizens and innovation stakeholders are not online and have limited understanding of emerging technologies, as shown by the recent South African Social Attitudes Survey (SASAS) module on the 4IR (Roberts et al. 2019). Thus, it becomes necessary to facilitate practical interaction with emerging technologies, such as through local makerspaces or local open space sessions, through which citizens can develop an understanding of the 'more abstract concepts and possibilities' relevant to policy issues (Smith and Stirling 2017, 78). Whilst ICT-supported open innovation platforms - and similar participatory approaches to innovation like Living Labs - may have a role to play in opening up decision-making, government actors need to anticipate that there will be resistance by incumbents to changes in power relations, but also by grassroots actors (and sympathetic researchers and civil servants) to an individualised, techno-economic focus on commercial innovation outcomes. To support grassroots action, public officials will need to go beyond just creating 'open' platforms or regulations, they will need work more directly with local actors to mediate value conflicts (Grotenbreg and Altamirano 2017) but also navigate peer, elite and organisational pressures which inhibit authentic grassroots participation (Joshi and McCluskey 2018; Cullen et al. 2014).

In conclusion, open government has been proclaimed as the ideal form of governance in modern society. Supra-national institutions, such as the OGP, promote open government globally and the use of ICTs, advocating its benefits, including the realisation of more participatory innovation processes and equitable development. Yet, as we have sought to note here, there is little inherent in the idea of openness which leads to inclusivity, and instead inclusivity must be continually pursued and sought out as movements and alternative framings of innovation outcomes develop at the fringes of government ICT, STI and development programmes. This is a particularly critical point for a country like South Africa which is facing serious issues of inclusivity across all facets of society, specifically in terms of race, gender and ill-distributed economic benefit.

\section{Notes}


${ }^{1} \mathrm{https}: / /$ www.dirisa.ac.za/

${ }^{2}$ http://bioenergy.org.za/

${ }^{3} \mathrm{https}: / /$ evaluations.dpme.gov.za/

${ }^{4} \mathrm{https}: / /$ opendataza.gitbook.io/toolkit/

${ }^{5}$ See WhereIsMyTransport https://www.whereismytransport.com/ and AftaRobot http://www.aftarobot.com/

${ }^{6} \mathrm{See}$ projects by OpenUp https://openup.org.za/ and Open Data Durban https://opendata.durban/odd/home

${ }^{7} \mathrm{https}: / /$ scoda.herokuapp.com/demographics

${ }^{8} \mathrm{https}: / / \mathrm{cbm}$. blacksash.org.za/

${ }^{9}$ https://www.mobisafaids.net/

${ }^{10}$ See Codebridge Youth project https://codebridgeyouth.org.za/

${ }^{11}$ See Narratives of Home project at Durban University of Technology https://www.dut.ac.za/faculty/engineering/urban_futures/projects/

${ }^{12}$ Such as the Centre for Environmental Rights https://cer.org.za/

${ }^{13}$ See an example of air quality monitoring by South Durban Community Environmental Alliance https://sdcea.co.za/download/sdcea-air-quality-monitoring-results-from-march-to-july$2017 /$

${ }^{14} \mathrm{https}: / / \mathrm{www} . r u . a c . z a /$ elrc/projects/t-learning/

${ }^{15} \mathrm{https}: / / \mathrm{www}$.activateleadership.co.za/what-we-do/

${ }^{16} \mathrm{https}: / / \mathrm{www} \cdot$ sanren.ac.za/

${ }^{17} \mathrm{https}: / /$ codebridge.org.za/

${ }^{18} \mathrm{https}: / /$ geekulcha.com/

${ }^{19} \mathrm{http}: / /$ themakerspace.co.za/

${ }^{20} \mathrm{https}: / /$ www.mafihub.co.za/

${ }^{21} \mathrm{https}: / /$ thepeople.co.za/

${ }^{22} \mathrm{https}: / /$ future.geekulcha.com/debate/

${ }^{23} \mathrm{http}: / /$ fakugesi.co.za/

${ }^{24} \mathrm{https}$ ://wiser.wits.ac.za/page/programme-african-digital-humanities-2018-2023-13069

${ }^{25} \mathrm{http}: / / \mathrm{www}$.simodisa.org/pages/policy

${ }^{26} \mathrm{https} / / /$ vulekamali.gov.za/events 


\section{References}

Abbott, J. 2019. An open letter to the Deep Learning Indaba team 2019 edition. Accessed August 18 2019. https://medium.com/@alienelf/an-open-letter-to-the-deep-learning-indaba-team-2019edition-6f86fddb1cc8.

Adams, R. 2018. "The Illusion of Transparency: Neoliberalism, Depoliticisation and Information as Commodity." Available at SSRN: https://papers.ssrn.com/sol3/papers.cfm?abstract_id=3281074.

Adams, R. and F. Adeleke. 2016. "Assessing the potential role of open data in South African environmental management." The African Journal of Information and Communication 19: 79-99.

Birchall, C. 2011. "Introduction to 'Secrecy and Transparency': The Politics of Opacity and Openness." Theory, Culture and Society 28 (7-8): 7-25. doi:https://doi.org/10.1177/0263276411427744.

Birchall, C. 2014. "Aesthetics of the secret." New Formations 83 (1): 25-46.

Calandro, E., A. Gillwald, A., C. Lewis, O. Mothobi and B. Rademan. 2018. Submission on the South African Electronic Communications Amendment Bill. Cape Town: Research ICT Africa. Accessed April 29 2019. https://techcentral.co.za/wpcontent/uploads/2018/02/ResearchICTAfrica_ECA_Bill_2017.pdf.

Cullen, B., J. Tucker, K. Snyder, Z. Lema and A. Duncan. 2014. "An analysis of power dynamics within innovation platforms for natural resource management." Innovation and Development 4(2): 259-75.

de Beer, J. 2017. "Open Innovation in Development: Integrating Theory and Practice Across Open Science, Open Education, and Open Data." openAIR, Working Paper 3.

DSI. 2016. Draft IID Strategy. Pretoria: Department of Science and Innovation, Republic of South Africa.

DSI. 2019. White Paper on Science, Technology and Innovation. Pretoria: Department of Science and Innovation, Republic of South Africa.

Erkkilä, T. 2010. "Transparency and Nordic Openness: State Tradition and New Governance Ideas in Finland" in Transparenz, edited by S.A. Jansen, E. Schröter and N. Stehr, 348-372. Wiesbaden: VS Verlag. 
Fressoli, M., E. Arond, D. Abrol, A. Smith, A. Ely, and R. Dias. 2014. "When Grassroots Innovation Movements Encounter Mainstream Institutions: Implications for Models of Inclusive Innovation.” Innovation and Development 4(2): 277-292.

Gillwald, A. 2005. "A closing window of opportunity: Under-serviced area licensing in South Africa." Information Technologies and International Development 2 (4):1-19.

Gray, J. 2014. "Towards a genealogy of open data." Paper presented at European Consortium for Political Research (ECPR) general conference, Glasgow, September 3-6.

Grönlund Å. 2010. “Ten Years of E-Government: The 'End of History' and New Beginning.” In Electronic Government, $9^{\text {th }}$ IFIP WG 8.5 International Conference, EGOV 2010, Lausanne, Switzerland, August/September 2010, edited by M.A. Wimmer, J-L. Chappelet., M. Janssen, and H.J. Scholl, 13-24. Berlin: Springer.

Grotenbreg, S. and M. Altamirano. 2017. "Government facilitation of external initiatives: How Dutch water authorities cope with value dilemmas". International Journal of Water Resources Development 35 (3): 465-490. doi:doi.org/10.1080/07900627.2017.1374930.

Harsh, M., T. S.Woodson, S. Cozzens, J. M.Wetmore, D. Soumonni, and R. Cortes. 2017. "The Role of Emerging Technologies in Inclusive Innovation: The Case of Nanotechnology in South Africa." Science and Public Policy 45(5): 597-607. doi:doi.org/10.1093/scipol/scx079.

Heeks, R. and S. Shekhar. 2019. "Datafication, development and marginalised urban communities: an applied data justice framework." Information, Communication \& Society 22 (7): 992-1011.

Henman, P. 2010. Governing Electronically: E-Government and the Reconfiguration of Public Administration, Policy and Power. New York: Palgrave Macmillan.

Howard, M. 2001. "E-Government Across the Globe: How Will 'e' Change Government" Government Finance Review. 17: 6-9.

Hugo, W. and J. Pauw. 2015. DIRISA Guidelines Policies and Licensing. Preliminary Guideline. Document Reference: G805.4.1.5.1 Version: Draft. Pretoria: Council for Scientific and Industrial Research.

Jonnalagadda, 1. and A. Maier. 2019. "Barriers to Government's Adoption of User-centered Design — And How To Address Them.” 18F. November 7. https://18f.gsa.gov/2019/11/07/barriers-togovernments-adoption-of-user-centered-design-and-how-to-address-them/. 
Joshi, A. and R. McCluskey. 2017. "The art of 'bureaucraft': Why and how bureaucrats respond to citizen voice." Making All Voices Count Research Briefing. Brighton: IDS.

Kelty, C. M. 2008. Two bits: The cultural significance of free software. Durham: Duke University Press.

Kosack, S. and A. Fung. 2014. "Does transparency improve governance?" Annual Review of Political Science 17: 65-87. doi:doi.org/10.1146/annurev-polisci-032210-144356.

Lacan, J. 1991. "The Other Side of Pscyhoanalysis" Edited by J. Lacan and J.-A. Miller. New York: W.W. Norton \& Company.

Limpopo Connexion. 2007. Limpopo FOSS Strategy. Accessed May 252019. https://limpopoconnexion.co.za/limpopo-foss-strategy/

Margetts, H. 2011. "The Internet and Transparency.” The Political Quarterly 82 (4): 518-521. doi:doi.org/10.1111/j.1467-923X.2011.02253.x.

McFarlane, C. 2016. "Towards more Inclusive Smart Cities? Digital Fragments in the Slum.” In Beware of smart people! Redefining the smart city paradigm towards inclusive urbanism: Symposium Proceeedings, Berlin, June 19-20, edited by J. Stollman, K. Wolf, A. Bruck, S. Frank, A. Million, P. Misselwitz, J. Schlaack, C. Schroder, 89-94. Berlin: University of Technology Berlin.

Moilanen, S. 2019. "When to Use User-Centered Design for Public Policy." Stanford Social Innovation Review, May 19. https://ssir.org/articles/entry/when_to_use_user_centered_design_for_public_policy

Ncube C.B., L. Abrahams, and T. Akinsanmi T. 2013. "Effects of the South African IP Regime on Generating Value from Publicly Funded Research: An Exploratory Study of Two Universities" in Innovation and Intellectual Property: Collaborative Dynamics in Africa, edited by J. De Beer, C. Armstrong, C. Oguamanam, and T. Schonwetter, 282 - 315. Cape Town: University of Cape Town Press.

Ngoepe, K. 2018. “Limpopo’s R580m broadband fiasco.” IOL, August 12. Accessed February 20 2019. https://www.iol.co.za/sundayindependent/news/limpopos-r580m-broadband-fiasco16511518 
NRF (National Research Foundation). 2015. "Statement on Open Access to Research Publications from the National Research Foundation (NRF)-Funded Research.” NRF. Jan 19. https://www.nrf.ac.za/media-room/news/statement-open-access-research-publications-nationalresearch-foundation-nrf-funded

NRF (National Research Foundation). 2019. "São Paulo Statement on Open Access." NRF. May 2. https://www.nrf.ac.za/media-room/news/s\%C3\%A3o-paulo-statement-open-access

OECD (Organisation for Economic Co-operation and Development). 2019. OECD Declaration on Public Sector Innovation. May 22. https://oecd-opsi.org/projects/innovationdeclaration-2/

OGP (Open Government Partnership). 2011. Open Government Declaration. September 20. https://www.opengovpartnership.org/process/joining-ogp/open-government-declaration/

Pandor, N. 2017. “Guiding nation's optimum adoption of bioenergy.” Mail \& Guardian. March 31. https://mg.co.za/article/2017-03-31-00-guiding-nations-optimum-adoption-of-bioenergy

Plantinga, P., E. Khomane, T. Nghonyama, P. Gwaze,, and A. Makau. 2018. "Hackathons and TrainUps: Engaging New Users of Air Quality Data.” Clean Air Journal 28(2): 21-23.

Roberts, B., J. Struwig, N. Bohler-Muller, S. Gordon, T. Zondi, S. Mtyingizane, and N. Mchunu. 2019. "Public attitudes towards the Fourth Industrial Revolution (4IR) in South Africa." HSRC Media Briefs. http://www.hsrc.ac.za/en/media-briefs/democracy-goverance-and-servicedelivery/public-attitudes-4ir

SANews. 2019. "Building a capable 4IR army". July 5 2019. https://www.sanews.gov.za/southafrica/building-capable-4ir-army

Schauer, F. 2011. "Transparency in Three Dimensions." University of Illinois Law Review 2011: 1339-1358.

Shibasaki, R. 2017. Call detail record (CDR) analysis: Republic of Guinea. ITU.

Smith, M. L., L. Elder, and H. Emdon, H. 2011. "Open Development: A New Theory for ICT4D." Information Technologies and International Development 7 (1): iii-ix.

Smith, M. L. and K. Reilly. 2013. "Introduction.” In Open development: Networked innovations in international development, edited by K. Reilly and M. Smith, 1-13. Cambridge, M.A: MIT Press. 
Singh, P. J. and A. Gurumurthy. 2014. "Establishing Public-ness in the Network: New Moorings for Development-A Critique of the Concepts of Openness and Open Development." In Open development: Networked innovations in international development, edited by K. Reilly and M. Smith, 173-196. Cambridge, M.A: MIT Press.

Smith, A. and A. Stirling. 2017. "Innovation, sustainability and democracy: an analysis of grassroots contributions." Journal of Self-Governance and Management Economics 6 (1): 64-97.

South African Government. 2019. President Cyril Ramaphosa appoints Commission on Fourth Industrial Revolution. April 9. https://www.gov.za/speeches/president-cyril-ramaphosa-appointscommission-fourth-industrial-revolution-9-apr-2019-0000.

Tkacz, N. 2012. "From Open Source to Open Government: A Critique of Open Politics." Ephemera: Theory and Politics in Organization 12 (4): 386-405.

UK Government. 2016. An introduction to Open Policy Making and design. February 1. London: Cabinet Office, UK Government. https://www.gov.uk/guidance/open-policy-makingtoolkit/getting-started-with-open-policy-making

Worthy, B. 2015. "The impact of open data in the UK: Complex, unpredictable, and political." Public Administration 93 (3): 788-805. doi:doi.org/10.1111/padm.12166 